shown an increase in the excretion of the 17-OHCS as well as of the 11-deoxy-17-oxosteroids in the first three days and a return to normal in about a week. A decrease in androsterone and aetiocholanolone excretion while there is an increase in 17-OHCS excretion after resection in lung cancer seems to be an unusual response to surgical stress and indicates a separation of the factors controlling the excretion and possibly the secretion of the precursors of the 17-OHCS and the 17-OS. This dissociation of the factors that control the excretion of the 17-OS and the 17-OHCS as a response to surgical stress may persist for several months both in breast cancer (Bulbrook and Hayward, 1967) and in lung cancer (Rao, unpublished), and may be a characteristic of neoplastic disease in general.

I thank Miss Margaret L. Hewit, who carried out many of these steroid determinations with the help of Mr. G. Lynam and Mr. A Clarke; Dr. R. J. Cuthbert, Dr. J. Cuthbert, Dr. J. T. Boyd, Mr. J. Hutcheson, Mr. M. A. Turner, Mr. R. A. McCluskie, and Mr.
R. S. Barclay for the facilities to investigate patients under their care; the nursing staff for collecting specimens; and Professor T. Ferguson Rodger for his encouragement and interest. The Medical Research Council and the Tobacco Research Council provided financial assistance.

\section{References}

Adams, J. B., and Wong, M. S. (1968). Lancet, 2, 1163.

Birke, G., Franksson, C., and Plantin, L. O. (1955). Acta Endocrinologica (Kobenhavn), 18, 201.

British Medical fournal, 1968, 4, 5

Bulbrook, R. D., and Hayward, J. L. (1967). Current Concepts in Breast Cancer, ed. A. Segaloff, K. K. Mayer, and S. Debakey, p. 126. Baltimore, Williams and Wilkins.

Jones, J. E., Shane, S. R., Gilbert, E., and Flink, E. B. (1969). Fournal of Clinical Endocrinology, 29, 1.

Rao, L. G. S. (1970). Lancet, 2, 441

Rao, L. G. S., and Hewit, M. (1970). Lancet, 2, 1063.

\title{
Amenorrhoea in Anorexia Nervosa: Assessment and Treatment with Clomiphene Citrate
}

\author{
J. C. MARSHALL, T. RUSSELL FRASER
}

British Medical fournal, 1971, 4, 590-592

\section{Summary}

Seven patients with anorexia nervosa were studied, three during the acute stages of the illness, and four in whom weight gain had been achieved, but who suffered from persistent amenorrhoea of 18 to 79 months' duration.

In the acute stage all patients had low serum luteinizing hormone (LH) levels which were unresponsive to clomiphene citrate. In those who had regained weight the mean basal LH levels were normal, and they responded to clomiphene with an initial doubling of serum LH during administration of the drug, followed by a second peak of serum LH four to seven days after the drug was stopped. Menstruation occurred in these patients 13 to 19 days after the clomiphene was discontinued, and in two patients regular spontaneous menstruation was initiated.

The low LH levels unresponsive to clomiphene in the acute stage provide evidence for a hypothalamic abnormality in anorexia nervosa. After regain of body weight the drug seems to be effective in treating the amenorrhoea which may be persistent.

\section{Introduction}

Amenorrhoea is a constant feature of anorexia nervosa occurring in girls after puberty. It usually begins early in the disease, after some weight loss has occurred (Russell and Beardwood, 1968), though it may antedate weight loss in some patients (Kay and Leigh, 1954). Commonly menses return with the regain of normal weight but may be delayed for months or years after weight gain has been achieved (Crisp and Stonehill, 1971).

\footnotetext{
Endocrine Unit, Department of Medicine, Royal Postgraduate Medical School, London W12 0HS

J. C. MARSHALL, B.SC., M.R.C.P., M.R.C. Clinical Research Fellow T. RUSSELL FRASER, M.D., F.R.C.P., Professor of Clinical Endocrinology
}

Most workers agree that urinary gonadotrophin levels are low during the illness (Bell, Harkness, Loraine, and Russell, 1966; Rakoff, 1968; Russell, 1970) and that this is the explanation of the amenorrhoea, though the mechanism of the reduced gonadotrophin secretion remains obscure. Studies of urinary gonadotrophin excretion during refeeding have shown that some gonadotrophin secretion returns with regain of weight. However, this is not proportional to weight gained and is incomplete, normal cyclical changes not being seen (Russell and Beardwood, 1968).

Clomiphene citrate has been shown to stimulate pituitary gonadotrophin secretion (Bardin, Ross, and Lipsett, 1967; Jacobson, Marshall, Ross, and Cargille, 1968; Marshall, Anderson, Burke, Galvao-Teles, and Fraser, 1970), but few data are available on its effect in anorexia nervosa or of its use as a therapeutic agent to stimulate the return of normal menses in this condition.

\section{Patients and Methods}

The diagnosis of anorexia nervosa was made using the criteria described by Russell (1970). Clinical details of the patients studied are given in the Table. Matched mean population weights were obtained from tables (Kemsley, 1952).

Serum luteinizing hormone $(\mathrm{LH})$ was measured with a double-antibody immunoassay. Medical Research Council Human Pituitary Research Standard "A" (ICSH/LH) 63/15 was used as the standard preparation. An ampoule of this material was defined as containing 10 "ampoule" units (hereafter termed units). In this assay 1 unit M.R.C. Standard "A" was equivalent to 8.4 international units of Second International Reference Preparation Human Menopausal Gonadotrophin. The normal range for the follicular phase of a menstrual cycle is $1.8-4.5 \mathrm{mU} / \mathrm{ml}$ (mean $2.7 \pm 0.49$ S.D.). Samples for $\mathrm{LH}$ estimation were taken before and at the end of clomiphene administration and when possible during the nine days after the course of clomiphene.

Clomiphene citrate (Clomid) was given in a dosage of $2 \mathrm{mg}$ / $\mathrm{kg} /$ day (50-75 mg/day) to patients in the acute stages of the illness, and in increasing doses (50-150 mg/day) to the anorexic 
Clinical Details of Patients with Anorexia Nervosa

\begin{tabular}{|c|c|c|c|c|c|c|c|c|}
\hline \multirow{2}{*}{$\begin{array}{l}\text { Case } \\
\text { No. }\end{array}$} & \multirow[b]{2}{*}{ Age } & \multicolumn{3}{|c|}{ Weight $(\mathrm{kg})$ and Percentage of Normal } & \multirow{2}{*}{$\begin{array}{l}\text { Age at and Date of Onset, } \\
\text { Course of Anorexia }\end{array}$} & \multirow{2}{*}{$\begin{array}{l}\text { Menarche } \\
\text { (Years) }\end{array}$} & \multirow[b]{2}{*}{ Menstrual History } & \multirow{2}{*}{$\begin{array}{c}\text { Duration of } \\
\text { Amenorrhoea } \\
\text { Before Test } \\
\text { (Months) }\end{array}$} \\
\hline & & $\begin{array}{l}\text { Before } \\
\text { Illness }\end{array}$ & $\begin{array}{l}\text { Minimum during } \\
\text { Illness }\end{array}$ & $\begin{array}{l}\text { At Time } \\
\text { Tested }\end{array}$ & & & & \\
\hline 1 & 22 & $52 \cdot 0(103 \cdot 8 \%)$ & $28.5\left(56.9^{\circ}\right)$ & $28.5\left(56 \cdot 9_{0}^{\circ}\right)$ & $\begin{array}{l}20 \text { years. June } 1969 . \\
\text { Inpatient Dec. 1970. } 5 \mathrm{~kg} \\
\text { weight gain }\end{array}$ & 12 & $\begin{array}{l}\text { Regular } 4 / 26 \text { for } 6 \text { months. } \\
\text { Occasional menses only } \\
\text { 1961-70. L.M.P. Aug. } 1970\end{array}$ & 4 \\
\hline 2 & 19 & $53.5(93.2 \%)$ & $38 \cdot 0\left(66 \cdot 2 \%_{0}\right)$ & $\begin{aligned} & 38 \cdot 0\left(66 \cdot 2{ }_{0}^{\circ}\right) \\
& \text { (1) } 41 \cdot 0\left(73 \cdot 2{ }_{0}\right)\end{aligned}$ & $\begin{array}{l}171 \text { years. June } 1967 . \\
\text { Inpatient June } 1970.17 \mathrm{~kg} \\
\text { weight gain } \\
\text { 14! years. June } 1966 .\end{array}$ & 13 & $\begin{array}{l}\text { Regular 4/28 1963-9. On } \\
\text { Lyndiol Jan-July } 1969 . \\
\text { L.M.P. May } 1969\end{array}$ & 9 \\
\hline 3 & 18 & $57 \cdot 0(101 \cdot 8 \%)$ & $33 \cdot 0\left(58 \cdot 9^{\prime \prime}, 0\right)$ & 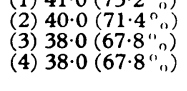 & $\begin{array}{l}\text { Inpatient } 1968.13 \mathrm{~kg} \text { weight } \\
\text { gain. Relapsed } 1969 . \text { In- } \\
\text { patient } 1971.7 .5 \mathrm{~kg} \text { weight } \\
\text { gain but relapsed }\end{array}$ & 12 & $\begin{array}{l}\text { Regular } 5 / 281964-7 . \\
\text { L.M.P. June } 1967\end{array}$ & 39 \\
\hline 4 & 22 & $45 \cdot 0\left(86 \cdot 5_{n}^{n}\right)$ & $25 \cdot 8\left(49 \cdot 6^{\circ}{ }_{0}\right)$ & $\begin{array}{l}\text { (1) } 41 \cdot 5\left(75 \cdot 6^{n}{ }_{0}\right) \\
\text { (2) } 41 \cdot 5\left(75 \cdot 6^{\prime \prime},{ }_{1}\right) \\
\text { (3) } 45 \cdot 0\left(81 \cdot 9^{\prime \prime}\right) \\
\text { (4) } 45 \cdot 0\left(81 \cdot 9^{\prime \prime},{ }_{0}\right)\end{array}$ & $\begin{array}{l}16 \text { years. June } 1963 \text {. } \\
\text { Inpatient. No response } \\
\text { during } 1963 \text { and } 1964 . \\
\text { Slow weight gain } 1967-9\end{array}$ & 11 & $\begin{array}{l}\text { Regular 4/28 1960-3. } \\
\text { L.M.P. Jan. } 1963\end{array}$ & 79 \\
\hline 5 & 19 & $53 \cdot 4\left(110 \cdot 1{ }_{11}\right)$ & $34 \cdot 3\left(70 \cdot 7^{\circ}{ }_{0}\right)$ & $\begin{array}{l}\text { (1) } 50 \cdot 0\left(96^{n}\right) \\
\text { (2) } 50.0(96 " n)\end{array}$ & $\begin{array}{l}15 \text { years. Jan. } 1967 \text {. } \\
3 \text { inpatient admissions } \\
\text { followed by relapses 1967-9. } \\
\text { Gradual weight gain during } \\
1970\end{array}$ & 11 & $\begin{array}{l}\text { Regular 5/28 1962-7. } \\
\text { Irregular Jan-May } 1967 . \\
\text { Treated with Tova } 1967 . \\
\text { L.M.P. July } 1967 \\
\text { (withdrawal bleed) }\end{array}$ & 45 \\
\hline 6 & 16 & $48.5\left(95 \cdot 8_{0}^{\circ}\right)$ & $39 \cdot 5\left(75.9{ }_{0}^{\prime}\right)$ & $43 \cdot 0\left(82 \cdot 6^{\prime \prime}, 1\right)$ & $\begin{array}{l}15 \text { ycars. Scpt. } 1969 . \text { Weight } \\
\text { regain during } 1970\end{array}$ & 13 & $\begin{array}{l}\text { Regular 5/28 1967-9. } \\
\text { L.M.P. Sept. } 1969\end{array}$ & 18 \\
\hline 7 & 22 & $57 \cdot 3\left(98 \cdot 6^{\prime}, 0\right)$ & $38 \cdot 2\left(65 \cdot 7_{0}^{\circ}\right)$ & $58.6\left(98.9^{n}\right)$ & $\begin{array}{l}\text { 20 ycars. Jan. 1969. Gradual } \\
\text { weight gain during } 1970 \text { and } \\
1971\end{array}$ & 13 & $\begin{array}{l}\text { Irregular 1958-63. Regular 5/28 } \\
\text { 1963-9. L.M.P. Jan. } 1969\end{array}$ & 29 \\
\hline
\end{tabular}

patients who had regained weight. The dose was increased by $25 \mathrm{mg} /$ day if the patient had not menstruated after the previous test.

Clomiphene tests were performed on three patients (Cases 1-3) during the acute stage of the illness and on four (Cases 4-7) after recovery of body weight. Additionally, serial tests were performed in Case 4 during recovery and in Case 3 whose initial weight gain in hospital was followed by relapse and weight loss.

\section{Results}

Three patients were studied during the acute stages of the illness (Fig. 1). All had low basal LH values, mean $1.0 \mathrm{mU} / \mathrm{ml}$ ( \pm 0.05 S.D.), and showed no response to clomiphene, either in serum LH or by subsequent menses.

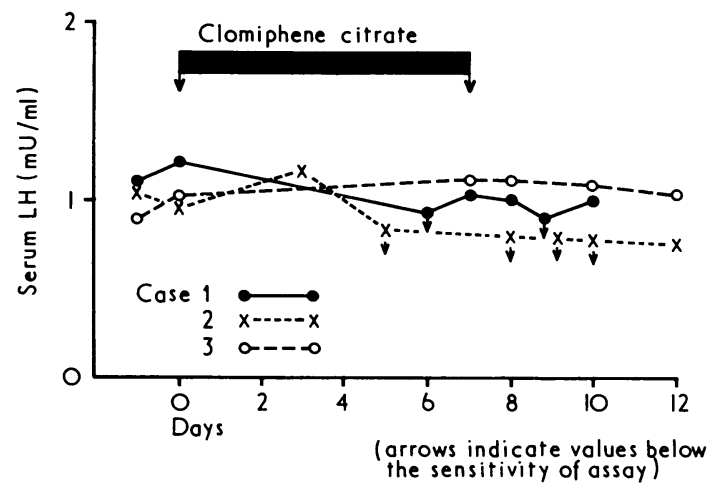

FIG. 1-Serum LH levels after administration of clomiphene citrate during the acute weight loss stage of anorexia nervosa.

Six tests were performed in four patients who remained amenorrhoeic despite considerable weight gain following treatment (Fig. 2). Basal serum LH levels, mean $2.0 \mathrm{mU} / \mathrm{ml}$ ( \pm 0.5 S.D.), were higher than those in the acutely ill subjects $(P=0.01)$. All four patients showed a rise in serum LH during the period of drug administration, the increase being a doublingmean, day $7,4.1 \mathrm{mU} / \mathrm{ml}$ ( \pm 0.8 S.D.) $(\mathrm{P}<0.001)$. Where $\mathrm{LH}$ levels were measured after clomiphene was stopped (threc tests), a second peak of serum $\mathrm{LH}$ (mean $7 \cdot 1 \mathrm{mU} / \mathrm{ml}$ ) was seen four to seven days after the drug was discontinued. Menstrual bleeding occurred in all four patients 13-19 (mean 14.7) days after clomiphene was stopped. In two patients, however, on the first occasion that an $\mathrm{LH}$ response was seen the $\mathrm{LH}$ rise was not followed by menstruation, though this did occur in subsequent tests.

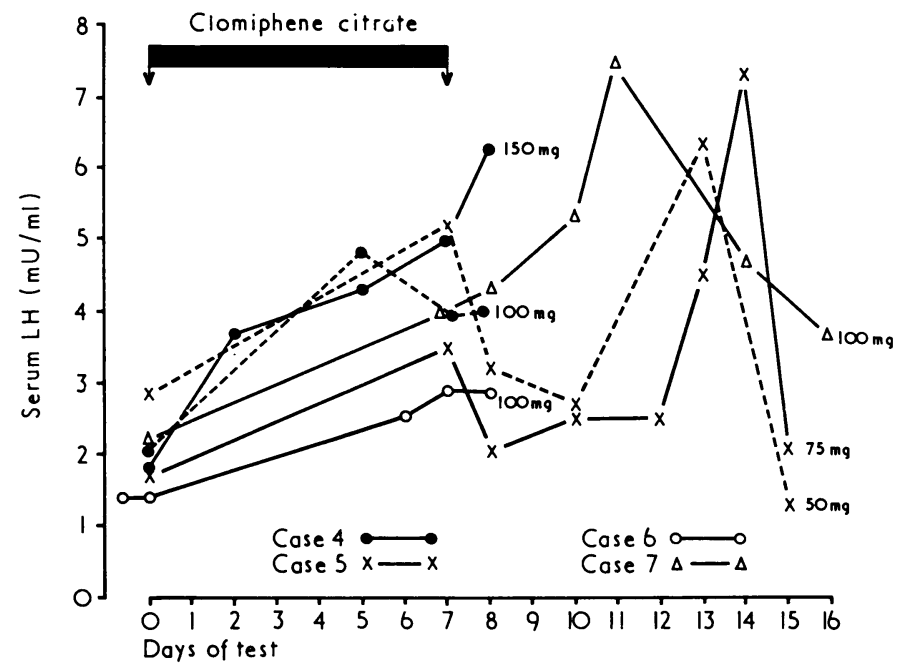

FIG. 2--Responses of serum LH in patients following weight gain. The dosage of clomiphene used in each test is shown. Responses followed by menstruation are shown as solid lines.

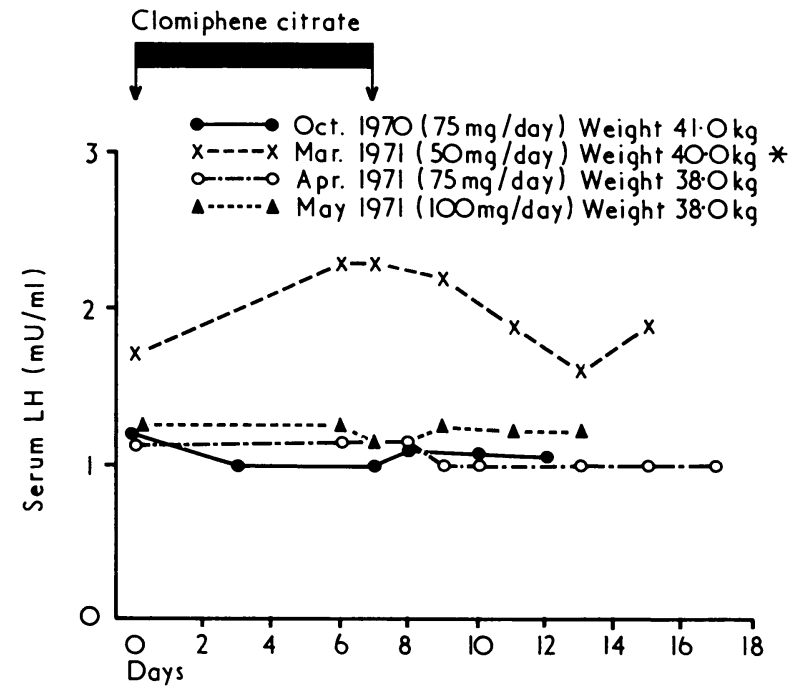

FIG. 3-Case 3. Serum LH during administration of clomiphene, before and after hospital treatment of anorexia nervosa. *After discharge from hospital (had gained $7 \mathrm{~kg}$ in weight in three weeks) 
One patient (Case 3) was studied immediately before rapid weight loss and after hospital treatment (weight gain $7 \mathrm{~kg}$ ), with further tests being performed during her subsequent relapse (Fig. 3). During the initial test basal LH levels were low and no response to clomiphene was seen. After hospital weight gain borderline normal LH levels were seen and a slight response occurred, but with no subsequent LH peak. During her relapse low $\mathrm{LH}$ levels and complete unresponsiveness were noted on two occasions despite the increased dosage of clomiphene being used.

Case 4 was studied during the recovery phase of her illness, when she was gaining weight at home (Fig. 4). In the first two tests low or normal $\mathrm{LH}$ values were seen but no response of

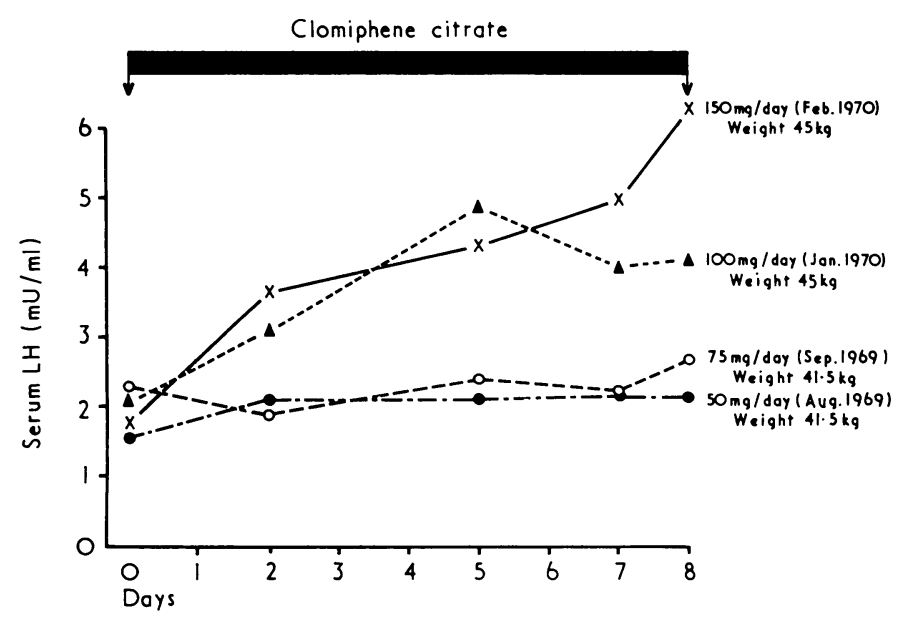

FIG. 4-Case 4. Serum $\mathrm{LH}$ after serial clomiphene administration during recovery of anorexia. Response $\mathrm{X}-\mathrm{X}$ was followed by menstruation.

serum LH occurred. Four months later (after a weight gain of $3.5 \mathrm{~kg}$ ) normal basal $\mathrm{LH}$ levels were seen and serum $\mathrm{LH}$ doubled during clomiphene administration, the test on the later occasion being followed by menstruation.

In two patients in whom follow-up was of adequate length, spontaneous regular inenses followed the response to clomiphene. These have continued for 11 months in Case 4 and for four months in Case 5.

\section{Discussion}

Our results showing low serum $\mathrm{LH}$ values during the acute illness confirm the findings of previous workers using bioassays of urine samples. Bell et al. (1966) showed that urinary gonadotrophin excretion increased after refeeding, and in some patients returned to normal values, but that cyclical changes did not occur. Similarly we found increased serum $\mathrm{LH}$ values in patients following regain of weight, three having values within the normal range.

As these patients were still amenorrhoeic the finding of normal serum LH levels suggests that they have a persistent hypothalamic disorder whereby the normal midcycle peak of LH secretion does not occur. A hypothalamic disturbance has long been postulated as the cause of pituitary hypofunction in anorexia nervosa, but definite evidence has been lacking. Pituitary hypofunction seems to be restricted to gonadotrophin secretion, as thyroid function is normal (Bliss and Migeon, 1957) and increased secretion of growth hormone and cortisol has been described (Marks, Howorth, and Greenwood, 1965).

Clomiphene citrate acts by blocking the hypothalamic feedback mechanisms for testosterone and oestrogen (Bardin et al., 1967; Marshall et al., 1970; Vaitukaitis, Bermudez, Cargille, Lipsett, and Ross, 1971). The lack of response to clomiphene in the early stages of anorexia nervosa provides additional evidence of a hypothalamic abnormality. This abnormality is reversible, as in patients after refeeding normal female $\mathrm{LH}$ responses to clomiphene are seen. This $\mathrm{LH}$ response is similar to that described by Jacobson et al. (1968) in anovulatory women, and by Yen, Vela, and Ryan (1970) in polycystic ovarian disease, $\mathrm{LH}$ levels doubling during clomiphene therapy, with a second $\mathrm{LH}$ peak occurring some four to seven days after the drug was stopped.

The factors which determine the return of clomiphene responsiveness remain unclear. Regain of weight may be a factor, and all the patients who responded had achieved $81 \%$ or more of their ideal body weight at the time of response. The exact dosage of clomiphene used does not seem to be important, as in one patient (Case 3) who relapsed after hospital treatment increasing clomiphene doses remained ineffective. Also the only slight response seen in this patient occurred on a low dose of clomiphene, immediately after weight gain in hospital.

Menstruation followed the $\mathrm{LH}$ response to clomiphene in all four patients, and in the two where a reasonable length of follow-up is available (Cases 4 and 5), regular spontaneous menstruation has been resumed after this test. The failure to menstruate after the first $\mathrm{LH}$ response in two subjects probably reflects the ovary failing to respond to the increased LH secretion. Indeed as these two subjects had presumably not had cyclical LH secretion for 79 and 45 months respectively, lack of ovulation after the first $\mathrm{LH}$ response is perhaps to be expected. The results of clomiphene stimulation to the few patients reported here suggest that this drug can be an effective means of treating persistent amenorrhoea in anorexic patients who have regained body weight.

A more detailed prospective study of the use of clomiphene in anorexia nervosa is at present being undertaken in conjunction with Professor G. F. M. Russell.

We are grateful to Drs. H. Dowling and G. M. Besser for allowing us to study patients under their care, and to Dr. J. P. Birkett, of Richardson-Merrell, for the supplies of Clomid. One of us (J.C.M.) is in receipt of a Medical Research Council Clinical Research Fellowship and the work was supported by an M.R.C. Research project grant and equipment grants to Professor Russell Fraser.

\section{References}

Bardin, C. W. Ross, G. T., and Lipsett, M. B. (1967). Fournal of Clinical Endocrinology and Metabolism, 27, 1558

Bell, E. T., Harkness, R. A., Loraine, J. A., and Russell, G. F. M. (1966) Acta Endocrinologica (Kobenhavn), 51, 140.

Bliss, E. L., and Migeon, C. J. (1957). Fournal of Clinical Endocrinology and Metabolism, 17, 766.

Crisp, A. H., and Stonehill, E. (1971). British Medical fournal, 3, 149.

Jacobson, A., Marshall, J. R., Ross, G. T., and Cargille, C. M. (1968). American fournal of Obstetrics and Gynecology, 102, 284

Kay, D. W. K., and Leigh, D. (1954). Fournal of Mental Science, 100, 411 Kemsley, W. F. F. (1952). Annals of Eugenics, 16, 316

Kemsley, W. F. F. (1952). Annals of Eugenics, 16, 316. Marks, V., Howorth, N., and Greenwood, F. C. (1965). Nature, 208, 687. Fraser, T. R. (1970). fournal of Endocrinology, 48, xxxix.
Foll,

Rakoff, A. E. (1968). Endocrinology and Human Behaviour, ed. R. P. Michael p. 139. London, Oxford University Press.

Russell, G. F. M. (1970). Modern Trends in Psychological Medicine 2, ed. J. H. Price, p. 131. London, Butterworth

Russell, G. F. M., and Beardwood, C. J. (1968). Endocrinology and Human Behaviour, ed. R. P. Michael, p. 310. London, Oxford University Press. Vaitukaitis, J. L., Bermudez, J. A., Cargille, C. M., Lipsett, M. B., and Ross, G. T. (1971). Journal of Clinical Endocrinology and Metabolism, 32, 503. Yen, S. S. C., Vela, P., and Ryan, K. J. (1970). Fournal of Clinical Endocrinology and Metabolism, 31, 7. 